\title{
Rethinking the Essential Facilities Doctrine for the EU Digital Economy
}

\author{
Inge GRAEF
}

Réviser la théorie des facilités essentielles dans

l'économie numérique européenne

Reconsiderar la doctrina de las instalaciones esenciales en la economía digital europea

Repensar a teoria das infraestruturas essenciais para a economia digital da EU

反思欧盟数字经济中的 “必要设施原则”

\section{Résumé}

La théorie des «facilités» ou infrastructures essentielles constitue une part importante de la loi sur la concurrence de l'Union européenne. Bien que peu utilisée récemment dans le cadre du contrôle de la concurrence, cette doctrine est régulièrement citée dans les discussions politiques de l'UE comme un moyen d'ouvrir des marchés pour lesquels les "géants de la technologie» agissent comme gardiens des entreprises et des consommateurs. L'économie numérique n'étant pas alimentée par les infrastructures physiques à l'origine de la doctrine des facilités essentielles, telles que les ponts de l'affaire

\section{Abstract}

The essential facilities doctrine forms an important part of EU competition law. Although it has not been used recently in EU competition enforcement, the doctrine is regularly referred to in EU policy discussions as a tool to open up markets in which 'tech giants' act as gatekeepers to businesses and consumers. Considering that the digital economy is not driven by physical infrastructures, such as the bridges in the US Terminal Railroad case from which the essential facilities doctrine originates, other assets like data or rankings - considered as the backbone of many digital markets - may become the subject

* Assistant professor at Tilburg University, affiliated to the Tilburg Institute for Law, Technology, and Society (TILT) and the Tilburg Law and Economics Center (TILEC). 
US Terminal Railroad, d'autres actifs centraux des marchés numériques, tels que les données ou les classements, sont appelés à devenir l'objet de réclamations. Cet article explore des moyens de repenser la doctrine des facilités essentielles afin de l'appliquer efficacement à de tels attributs de l'économie numérique européenne. Une attention particulière est accordée aux caractéristiques du marché, aux récentes affaires Google qui semblent contourner la doctrine des facilités essentielles et aux développements législatifs et politiques régissant l'accès en dehors du droit de la concurrence de l'UE. Afin de faire revivre la doctrine des facilités essentielles dans l'économie numérique européenne, des suggestions sont finalement avancées pour mieux aligner son application sur les intérêts économiques sous-jacents.

\section{Resumen}

La doctrina de las «facilidades» instalaciones o infraestructuras esenciales constituye una parte importante de la ley de competencia de la Unión Europea. Aunque poco utilizada en los últimos tiempos en el contexto de control de la competencia, esta doctrina se cita regularmente en las discusiones políticas de la UE como una manera de abrir mercados en los cuales los "gigantes tecnológicos» actúan como guardianes de las empresas y de los consumidores. La economía digital al no estar ya impulsada por las infraestructuras físicas que dieron origen a la doctrina de instalaciones esenciales, tales como los puentes del caso US Terminal Railroad, otros activos centrales de los mercados digitales, como los datos o las clasificaciones, pueden ser llamados a convertirse en objeto de reclamaciones. of essential facilities claims. The article explores how the essential facilities doctrine can be rethought in order to be effectively applied to such assets in the EU digital economy. Attention is paid to market characteristics, the recent Google competition cases seemingly bypassing the essential facilities doctrine, and legislative and policy developments regulating access outside EU competition law. To revive the essential facilities doctrine for the EU digital economy, suggestions are made as to how its application can be better aligned with the underlying economic interests at stake.

\section{Resumo}

A teoria das facilities ou infraestruturas essenciais constitui uma parte importante da lei sobre a concorrência da União Europeia. Ainda que pouco utilizada recentemente no quadro do controle da concorrência, esta doutrina é regularmente citada nas discussões de políticas da UE como um meio de abrir os mercados em que os "gigantes da tecnologia" agem como guardiões para as empresas e os consumidores. Visto que a economia digital não é sustentada por infraestruturas físicas como as que estavam na origem da teoria das facilidades essenciais, tais como as pontes do caso US Terminal Railroad, outros ativos centrais do mercado digital, tais como os dados ou sua classificação, podem vir a se tornar o objeto das reclamações. Este artigo expõe os meios de repensar a teoria das infraestruturas 
Este artículo explora las maneras de replantear la doctrina de las instalaciones esenciales con el fin de aplicarla eficazmente a tales atributos de la economía digital europea. Se presta una atención particular a las características del mercado, a los casos recientes de Google que parecen pasar por alto la doctrina de las instalaciones esenciales y a los desarrollos legislativos y políticos que rigen el acceso fuera del derecho de la competencia de la UE. Finalmente, con el fin de revivir la doctrina de las instalaciones esenciales en la economía digital europea, se hacen sugerencias para ajustar mejor su aplicación sobre los intereses económicos subyacentes. essenciais para aplicá-la eficazmente a tais ativos da economia digital europeia. Uma atenção especial é dada às características do mercado, aos recentes casos Google que parecem contornar a teoria das infraestruturas essenciais e aos desenvolvimentos legislativos e políticos que regem o acesso fora do direito da concorrência da UE. Para reavivar a doutrina das infraestruturas essenciais na economia digital europeia, são propostas sugestões para melhor alinhar sua aplicação aos interesses econômicos subjacentes.

\section{摘要}

“必要设施原则” 是欧盟竞争法的一个重要组成部分。尽管这一概念很少 在反垄断调查中被使用，但它在欧盟的政策讨论中经常被引用，成为 “科技巨 头” 以企业和消费者看门人之名开辟市场的手段。源自必要设施原则的实体基 础设施并没有促进数字经济, 比如美国终点铁路公司（US Terminal Rai1road）案中的桥梁, 反倒是其他数字经济的重要资产, 如数据或排名, 成为投 诉的对象。本文探讨了怎样对 “必要设施原则” 这一理论进行反思, 以便将其 有效地适用于欧盟数字经济中的这些资产。本文尤其探讨了市场特征、最近的 谷歌反垄断案（该案似乎规避了这一理论）以及欧盟竞争法以外的关于市场准 入的立法和政策动向。为了在欧盟数字经济中复苏 “必要设施原则” 的理论, 文章最后提出了怎样将该理论的适用更好地对准潜在经济利益的建议。 



\section{Table of contents}

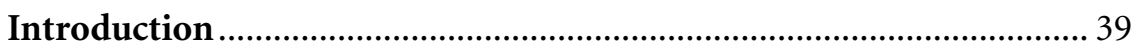

I. Evolution of the essential facilities doctrine ................................. 40

A. Commercial Solvents and Magill..................................................... 41

B. Bronner and IMS Health.................................................................. 43

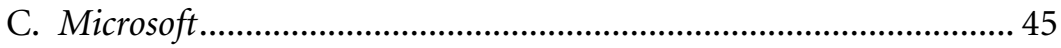

II. Balancing the interests at stake in light of underlying market

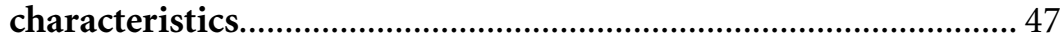

A. Sustaining versus disruptive innovation ...................................... 47

B. Competition in versus competition for the market ....................... 51

C. Application to the market characteristics of the digital economy.

III. Analysing the Google Shopping and Google Android cases through the lens of the essential facilities doctrine......................... 56

A. Google Shopping ............................................................................... 56

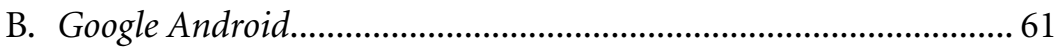

IV. Developments outside EU competition law .....................................63 63

V. Proposal for reviving the essential facilities doctrine for the EU digital economy .............................................................. 66

A. Exclusion of effective competition ................................................. 66

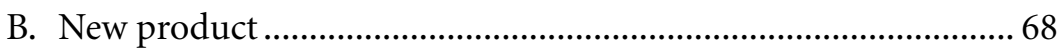

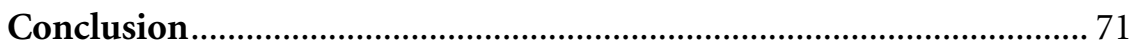



It was in 1912 that the US Supreme Court imposed a duty on a number of railroad companies to give competing railroad companies access to certain railroad bridges that they had acquired. The concern of the Supreme Court was that without this form of shared access these competitors could not offer they own railroad service beyond the Mississippi River. This would have damaged consumers by limiting their choice for competing services. The type of competition intervention that the United States Supreme Court established in this Terminal Railroad case ${ }^{1}$ later became known as the "essential facilities doctrine". The doctrine attacks a form of exclusionary conduct by which a dominant undertaking refuses to give access to a type of infrastructure or other form of asset that forms a "bottleneck" for rivals to be able to compete. Since its inception in US antitrust law, the doctrine has been adopted in the competition regimes of various jurisdictions around the world. ${ }^{2}$

The essential facilities doctrine has also played an important role in EU competition law, where the concept over the years has been applied to physical infrastructures, including ports and railroads, as well as to intangible assets protected by intellectual property rights. ${ }^{3}$ Although the essential facilities doctrine has not been applied recently anymore in EU competition enforcement, ${ }^{4}$ it is regularly referred to in EU policy discussions as a

United States $v$ Terminal Railroad Association of St. Louis, 224 US 383 (1912).

OECD, Competition Committee, The Essential Facilities Concept, Roundtables on Competition Policy, (Paris: OECD, 1996), online: <http://www.oecd.org/competition/ abuse/1920021.pdf>.

3 For a number of European Commission decisions involving access to port and railway infrastructures access in the 1990s, see EC, Commission Decision of 11 June 1992 relating to a proceeding under Article 86 of the EEC Treaty (IV/34.174 - B\&I Line PLC v. Sealink Harbours Ltd. \& Sealink Stena Ltd.), [1992] 5 CMLR 255; EC, Commission Decision 94/19/EC of 21 December 1993 relating to a proceeding pursuant to Article 86 of the EC Treaty (IV/34.689 - Sea Containers v. Stena Sealink - Interim Measures), [1994] OJ, L 15/8; EC, Commission Decision 94/119/EC of 21 December 1993 concerning a refusal to grant access to the facilities of the port of Rødby [Denmark], [1994] OJ, L 55/52; EC, Commission Decision 94/894/EC of 13 December 1994 relating to a proceeding under Article 85 of the EC Treaty and Article 53 of the EEA Agreement (IV/32.490 - Eurotunnel), [1994] OJ, L 354/66.

4 A recent development dates from September 2017 when the General Court upheld a Commission decision from October 2015 not to apply the essential facilities doctrine and not to open a competition investigation in a dispute between software companies. By doing so, the Commission rejected the complaint from Contact Software alleging that Dassault and Parametric abused their dominant positions by refusing to give Contact 
tool to open up markets in which "tech giants" act as gatekeepers to businesses and consumers. ${ }^{5}$ Considering that the digital economy is not anymore driven by physical infrastructures, such as the bridges in the US Terminal Railroad case, other assets like data or rankings as the backbone of many digital markets may form the subject of essential facilities claims. Access to data or being ranked by an online platform can now be essential for businesses to compete in the market.

Against this background, the paper explores how the essential facilities doctrine should be applied to bottleneck assets in the EU digital economy. This question is particularly examined from the perspective of whether there should be more room for competition interventions under the essential facilities doctrine in the digital economy, considering market characteristics (section II), as well as the recent Google competition cases seemingly bypassing the essential facilities doctrine (section III), and legislative and policy developments regulating access outside EU competition law (section IV). It is put forward that the essential facilities doctrine should be rethought in order to be effectively applied in the EU digital economy, in particular by aligning its application with the underlying economic interests. Attention is now first paid to how the essential facilities doctrine evolved in EU competition law (section I).

\section{Evolution of the essential facilities doctrine ${ }^{6}$}

The essential facilities doctrine forms an important part of current EU and US competition or antitrust law, in the context of respectively Article 102 of the Treaty on the Functioning of the EU (TFEU) and Section 2 of the Sherman Act. However, the US Supreme Court and the EU Courts have never formally recognized its existence. The US Supreme Court explicitly

Sofware access to interoperability information relating to computer-aided design software (Contact Software v Commission, T-751/15, ECLI:EU:T:2017:602).

5 See for instance, Autorité de la concurrence and Bundeskartellamt, Competition Law and Data (2016), online: <http://www.autoritedelaconcurrence.fr/doc/reportcompetition lawanddatafinal.pdf >; EC, Commission Staff Working Document on the free flow of data and emerging issues of the European data economy (2017) at 21-22, online: $<$ https://eurlex.europa.eu/legal-content/EN/TXT/PDF/?uri=CELEX:52017SC0002\&from=EN> at $17-18$.

6 This section partly reproduces earlier work in Inge Graef, EU Competition Law, Data Protection and Online Platforms: Data as Essential Facility (Wolters Kluwer, 2016) at 155-156, 163-173, 210-212. 
referred to the essential facilities doctrine in its Trinko judgment ${ }^{7}$ but neither approved nor refuted the doctrine. In the EU, the General Court and the Court of Justice have not mentioned the term "essential facilities doctrine" in their judgments, but instead refer to "refusals to deal" or "refusals to supply".

In scholarship, there is discussion about whether the two should be seen as separate concepts: refusals to deal would then involve cases of disruptions of supply where there is a pre-existing course of dealing between the dominant firm and the access seeker, and essential facilities cases would relate to access requests from new customers with whom the dominant firm has no existing business relationship. Such a differentiation is, however, not consistently applied in EU competition law where the indispensability or essentiality of the input is required in most instances irrespective of whether the access seeker is an existing or new customer. ${ }^{8}$ For this reason, the notions "refusal to deal/supply" and "essential facilities" are used interchangeably here in the context of EU competition law. The analysis below focuses on the key cases that have impacted the current legal standards in EU competition law.

\section{A. Commercial Solvents and Magill}

Commercial Solvents was the first case where a refusal to deal has been assessed under EU competition law. Commercial Solvents was the manufacturer of aminobutanol, a raw material necessary for the production of ethambutol that is used in the treatment of tuberculosis. Commercial Solvents stopped to supply the raw material to Zoja, its regular customer and competitor on the derivative market for the pharmaceutical substance ethambutol. The Court of Justice found that the conduct of Commercial Solvents constituted an abuse of dominance and upheld the imposition of

Verizon Communications v Law Offices of Curtis V. Trinko, LLP, 540 US 398 (2004) [Trinko]. See: Treaty on the Functioning of the EU, [2012] OJ C326 [TFEU] and Sherman Antitrust Act, 15 U.S.C. $\$ \$ 1-38$ (1890).

8 See for instance the 2007 Microsoft judgment where the General Court applied the indispensability requirement to the disruption of supply by Microsoft (Microsoft $v$ Commission, T-201/04, ECLI:EU:T:2007:289 [Microsoft]). However, the Court of Justice did deliver a judgment in a preliminary reference case in 2008 which may be interpreted in such a way as to set a different standard for disruptions of supply (Sot. Lélos kai Sia EE and Others $v$ GlaxoSmithKline AEVE Farmakeftikon Proïonton, joined Cases C-468/06 to C-478/06, ECLI:EU:C:2008:504). 
a fine by the European Commission. The Court argued that a dominant supplier abuses its dominant position when it refuses to supply to a customer which is at the same time a competitor in the derivative market "with the object of reserving such raw material for manufacturing its own derivatives" and "therefore risks eliminating all competition on the part of this customer".

In later cases, the Court of Justice also started looking at refusals to license intellectual property rights. An influential case is Magill where the Court of Justice upheld the judgment of the General Court and the decision of the European Commission ordering three Irish broadcasting companies to provide the publishing company Magill with a copyright license for the weekly listings of their television programmes. Magill was planning to introduce a comprehensive television guide consisting of the weekly programme listings of all three channels. Such a product was not available on the market in Ireland at that time, but the three broadcasting stations claimed copyright protection for their weekly programme listings and did not grant Magill the necessary licenses. In its judgment, the Court of Justice stated that in exceptional circumstances the exercise of an exclusive right may involve abusive behaviour. ${ }^{10}$ The Court then listed three circumstances which led to the conclusion that the conduct of the broadcasting companies amounted to abuse of dominance. Firstly, considering that the broadcasting companies were the only sources of the basic information on programme listings which is the indispensable raw material for compiling a comprehensive weekly television guide, they were able to prevent the appearance of a new product for which potential consumer demand existed. Secondly, there was no justification for the refusal to license either in the activity of television broadcasting or in that of publishing television magazines. Thirdly, the broadcasting companies reserved to themselves the secondary market of weekly television guides by excluding all competition on that market through their denial of access to the basic information indispensable for the compilation of such guides. ${ }^{11}$

\footnotetext{
$9 \quad$ Istituto Chemioterapico Italiano and Commercial Solvents $v$ Commission, joined cases 6 and 7/73, ECLI:EU:C:1974:18 at para 25.

10 Telefis Eireann and Independent Television Publications Ltd $v$ Commission of the European Communities (Magill), joined cases C-241/91 and C-242/91, ECLI:EU:C:1995:98 at para 50 [Magill].

$11 \quad$ Ibid at paras 52-56.
} 


\section{B. Bronner and IMS Health}

The requirement of indispensability was further interpreted in Bronner. The cases concerned a preliminary reference from an Austrian court and deal with a denial of access to a newspaper home-delivery scheme. Mediaprint and Oscar Bronner were both newspaper publishers in Austria. Only Mediaprint had a nationwide home-delivery scheme for newspapers in which it did not want to include the newspaper published by Oscar Bronner. The Court of Justice concluded that this behaviour of Mediaprint did not amount to abuse of dominance. In the Court's view, several alternatives were available for the distribution of Oscar Bronner's daily newspaper, such as delivery by post and sales in shops and at kiosks, even though they might be less advantageous. Furthermore, the Court noted that it was not enough for Oscar Bronner to argue that it is not economically viable to set up its own system due to the small circulation of its own newspaper. For such access to be capable of being regarded as indispensable, it would be necessary, in the Court's view, to establish at the very least that it is not economically viable to create a second home-delivery scheme with a circulation comparable to that of the newspapers distributed by the existing scheme. ${ }^{12}$

This restrictive approach can be explained by the possible long-term effects of the imposition of a duty to deal on competition and innovation. As Advocate General Jacobs made clear in his Opinion in Bronner, a duty to deal will increase competition in the short term but may put incentives for competitors to develop competing facilities in the long term at risk. In addition, the incentives of dominant undertakings to invest in new facilities may be reduced if competitors are given access too easily. In the words of the Advocate General: "In the long term it is generally pro-competitive and in the interest of consumers to allow a company to retain for its own use facilities which it has developed for the purpose of its business". ${ }^{13}$

The next essential facilities case was IMS Health which involved the refusal of IMS, a company active in providing data on regional sales of pharmaceutical products in Germany, to grant a license to its competitor NDC for the use of the copyrighted brick structure that IMS had developed

Oscar Bronner GmbH \& Co. KG v Mediaprint Zeitungs, C-7/97, ECLI:EU:C:1998:569 at paras 43-46.

13 See the opinion of Advocate General Jacobs in Oscar Bronner GmbH \& Co. KG v Mediaprint Zeitungs, C-7/97, ECLI:EU:C:1998:264 at para 57 [Bronner]. 
consisting of 1860 bricks, each corresponding with a certain geographical area. The judgment of the Court of Justice is particularly instructive for its statement that the fact that the requested input has never been marketed separately does not preclude the possibility of applying the essential facilities doctrine altogether. To this end, the Court referred to the Bronner judgment in which an upstream relevant market for home delivery of daily newspapers was defined even though Mediaprint had not marketed its homedelivery scheme as a separate product. ${ }^{14}$ In the Court's view, it therefore appeared that, for the purposes of the application of the earlier case law, the identification of "a potential or even a hypothetical market" for the asset to which access is requested is sufficient. According to the Court, this is the case "where the products or services are indispensable in order to carry on a particular business and where there is an actual demand for them on the part of undertakings which seek to carry on the business for which they are indispensable". ${ }^{15}$ The Court went on to explain that "it is determinative that two different stages of production may be identified and that they are interconnected, inasmuch as the upstream product is indispensable for the supply of the downstream product". ${ }^{16}$ In other words, an upstream market for the input can be defined as long as the access seeker is able to show that it needs the input in order to compete on a related downstream market.

On the legal test to be applied, the Court of Justice summarised that: "[i]t is clear from that case-law that, in order for the refusal by an undertaking which owns a copyright to give access to a product or service indispensable for carrying on a particular business to be treated as abusive, it is sufficient that three cumulative conditions be satisfied, namely, that that refusal is preventing the emergence of a new product for which there is a potential consumer demand, that it is unjustified and such as to exclude any competition on a secondary market". ${ }^{17}$ These conditions were also applied by the General Court in Microsoft, but the standard for their fulfilment has been lowered as compared to earlier cases.

14 IMS Health GmbH \& Co. OHG v NDC Health GmbH \& Co. KG, C-418/01, ECLI:EU: C:2004:257 at paras 42-43 [IMS Health].

$15 \quad$ Ibid at para 44.

$16 \quad$ Ibid at para 45.

$17 \quad$ Ibid at para 38. 


\section{Microsoft}

In 2004, the European Commission fined Microsoft for engaging in two types of abusive behaviour. ${ }^{18}$ The one of relevance here involves Microsoft's refusal to license so-called interoperability information to Sun. The latter was active in the downstream market for work group server operating systems and needed access to the interoperability information in order to let its services communicate with Microsoft's dominant client PC operating system Windows. Microsoft appealed the Commission decision to the General Court which delivered its judgment in the case in 2007.

Although the General Court relied on the same exceptional circumstances as taken into account in earlier cases, ${ }^{19}$ it followed the Commission in applying lower standards for the fulfilment of the conditions. With regard to the indispensability requirement, the General Court explained that in order to compete viably on the market it is necessary for competitors to be able to interoperate with Windows "on an equal footing" ${ }^{20}$ This while the Court of Justice made clear in Bronner that access is not indispensable if alternatives are available, even though they are less advantageous. The General Court also stated that it is not required for the Commission to demonstrate that all competition on the market is eliminated as a result of a refusal to license. What matters, in the view of the General Court, is that the refusal "is liable, or is likely to, eliminate all effective competition on the market". ${ }^{21}$

Concerning the new product condition, the General Court confirmed the finding of the Commission that the prevention of the appearance of a new product cannot be the only parameter for determining whether a refusal to license is capable of causing prejudice to consumers in the context of Article 102(b) TFEU. The General Court decided to follow the Commission in adopting a flexible stance on what can constitute a new product and argued that prejudice to consumers under Article 102(b) TFEU may occur "where there is a limitation not only of production or markets, but also of technical development". ${ }^{22}$ This is a considerably broader standard than the one applied by the Court of Justice in IMS Health where it was

Microsoft, COMP/C-3/37.792, 24 March 2004.

Microsoft, supra note 8 at paras 331-333.

Ibid at para 421.

Ibid at para 563.

Ibid at para 647. 
held that a refusal to license "may be regarded as abusive only where the undertaking which requested the license does not intend to limit itself essentially to duplicating the goods or services already offered on the secondary market by the owner of the intellectual property right, but intends to produce new goods or services not offered by the owner of the right and for which there is a potential consumer demand" ${ }^{23}$ Despite the fact that Sun could not identify a new product that it would offer once given access to the interoperability information, the new product circumstance was considered met on the ground that the refusal of Microsoft restricted technical development. ${ }^{24}$

As an objective justification for its refusal to license, Microsoft argued that the provision of interoperability information would have a negative effect on its incentives to innovate. However, the General Court concluded that the Commission had correctly dismissed this justification considering that Microsoft had not sufficiently established the negative impact on its innovation incentives but "merely put forward vague, general and theoretical arguments" without specifying the technologies or products in which its future incentives to invest would be eliminated..$^{25}$

Since Microsoft decided not to appeal the judgment, the Court of Justice did not get the chance to express its view on the case and on whether it endorses the application of the lower standards for the establishment of abuse for a refusal to license. For this reason, it remains uncertain if the Microsoft judgment sets out a new and more expansionist approach to refusals to deal or whether the reasoning of the European Commission and the General Court cannot be transposed to other cases considering the superdominant position of Microsoft in the market for client PC operating systems.

IMS Health, supra note 14 at para 49.

Microsoft, supra note 8 at para 665.

Ibid at paras 697-698. 


\section{Balancing the interests at stake in light of underlying market characteristics ${ }^{26}$}

The establishment of a violation of Article 102 TFEU or Section 2 of the Sherman Act in an essential facilities case results into the imposition of a duty to deal on the dominant firm. This is a far-reaching competition intervention, since it is at odds with the generally recognised principles of freedom to contract, ${ }^{27}$ including the right to choose one's trading partners, ${ }^{28}$ and freedom to dispose of one's property. ${ }^{29}$ The decision of a competition authority or court to interfere with the interests of a dominant undertaking for the purpose of protecting effective competition therefore requires careful balancing. This is not a straightforward exercise, considering that the protection of competition involves conflicting considerations. While a duty to deal increases short-term competition and innovation complementary to the facility of the dominant firm, it may diminish incentives for competitors as well as dominant firms to develop substitutes for the existing infrastructure in the long term. ${ }^{30}$ This is the trade-off that needs to be made in essential facilities cases.

\section{A. Sustaining versus disruptive innovation}

The trade-off can be presented as one between competition in the market and competition for the market. Although innovation is a complex

26 The reasoning set out in this section builds on and partly reproduces earlier work in I. Graef, supra note 6 at 68-72, 179-192.

27 In Bayer, the General Court explicitly acknowledged the freedom to do business in the context of the assessment of refusals to deal under Article 102 TFEU (at that time Article 86 TEEC): "The case-law of the Court of Justice indirectly recognises the importance of safeguarding free enterprise when applying the competition rules of the Treaty where it expressly acknowledges that even an undertaking in a dominant position may, in certain cases, refuse to sell or change its supply or delivery policy without falling under the prohibition laid down in Article 86" (Bayer v Commission, T-41/96, ECLI:EU: T:2000:242 at para 180).

28 The fact that the Sherman Act generally does not restrict the right of a firm to freely choose its trading partners was explicitly acknowledged by the US Supreme Court in United States v Colgate \& Co., 250 US 300 (1919), at 307. However, in Kodak the Supreme Court made clear that the right to refuse to deal with competitors is not absolute but exists only if there are legitimate competitive reasons for the refusal (Eastman Kodak Co. v Image Technical Services, Inc., 504 US 451 (1992), at 483). 
process that may have unpredictable outcomes, competition in and for the market each typically lead to a different type of innovation. In the business literature, Christensen has made a distinction between two types of technological innovations: sustaining and disruptive technologies. ${ }^{31}$ Sustaining technologies present some level of improvement of an existing product but retain the aspects of the product that customers value. ${ }^{32}$ They can be either of an incremental nature or have a breakthrough or radical character. Both types concern improvements of established products that do not affect existing markets. An incremental innovation is an improvement of a product in ways that customers expect, while a discontinuous or radical innovation is unexpected but nevertheless does not affect established markets. ${ }^{33}$ In this perspective, a sustaining technology develops within the value network, whereas a disruptive technology comes from outside the value network and displaces it. ${ }^{34}$

Disruptive technologies have features that differ from the ones that mainstream customers value and often perform worse in at least one dimension that is particularly important for these customers. ${ }^{35}$ An important characteristic of a disruptive technology is that the aspects of the new product that customers do value improve at such a rapid rate that the new technology permeates established markets. Products based on disruptive technologies have features that initially only a few customers value. Often,

31 The findings originally put forward in J.L. Bower \& C.M. Christensen, "Disruptive Technologies: Catching the Wave" (1995) 73:1 Harvard Business Review 43 have been further developed by Christensen in C.M. Christensen, The Innovator's Dilemma. When New Technologies Cause Great Firms to Fail (Boston, Massachusetts: Harvard Business School Press, 1997). In his later book that he co-authored with Raynor, Christensen changed the term "disruptive technology" to "disruptive innovation" arguing that it was not the technology itself that was disruptive but rather the use that companies made of it, or in other words the innovation that companies pursued by incorporating the new technology. See C.M. Christensen \& M.E. Raynor, The Innovator's Solution: Creating and Sustaining Successful Growth (Boston, Massachussets: Harvard Business School Press, 2003) at 32-34, n 3.

32 J.L. Bower \& C.M. Christensen, supra note 31 at 45.

33 C.M. Christensen, supra note 31 at 11. See C.M. Christensen \& M.E. Raynor, supra note 31 at $34, \mathrm{n} 3$.

34 Alexandre De Streel \& Pierre Larouche, "Disruptive innovation and competition policy enforcement”, Note for OECD Global Forum on Competition, 2015, online: <http:// www.oecd.org/officialdocuments/publicdisplaydocumentpdf/?cote=DAF/COMP/ $\mathrm{GF}(2015) 7 \&$ docLanguage $=\mathrm{En}>$ at 2.

35 J.L. Bower \& C.M. Christensen, supra note 31 at 45. 
they are cheaper, simpler and more convenient to use. ${ }^{36}$ For example, the reason why personal computers have replaced mainframe-computers is not because of their superior technical performance but because personal computers started to meet the needs of most customers. The same has happened with the introduction of tablets and smartphones relying on internet services and mobile applications that are gradually overtaking the market for personal computer hardware and software.

The distinction between sustaining and disruptive technologies or innovation is also reflected in essential facilities cases. The imposition of a duty to deal will stimulate competition in the market, encompassing competition in established markets on the basis of price and output as well as the introduction of sustaining innovation. A decision not to intervene in the market will instead primarily encourage competition for the market and disruptive innovation that attacks existing market structures and leads to the development of new markets. ${ }^{37}$ The latter type of competition typically results into a monopoly position that is likely to persist for some time, until a new monopolist comes up that overturns the position of the previous incumbent. Although competition for the market is not yet welldeveloped in the literature, it seems that in sectors mainly characterised by

36 C.M. Christensen, supra note 31 at 149-151.

37 See also David S. Evans \& Richard Schmalensee, "Some Economic Aspects of Antitrust Analysis in Dynamically Competitive Industries" in Adam B. Jaffe, Josh Lerner \& Scott Stern, eds, Innovation Policy and the Economy, vol. 2 (Cambridge, Massachussets: MIT Press, 2002) at 1. It is also possible to distinguish between competition ex ante (for the market) and competition ex post (in the market) - see Michael L. Katz \& Carl Shapiro, "Antitrust in Software Markets" in Jeffrey A. Eisenach \& Thomas M. Lenard, eds, Competition, Innovation and the Microsoft Monopoly: Antitrust in the Digital Marketplace (Kluwer Academic Publishers, 1999) 29 at 57. Damien Geradin, "Limiting the scope of Article 82 EC: What can the EU learn from the U.S. Supreme Court's judgment in Trinko in the wake of Microsoft, IMS, and Deutsche Telekom?" (2004) 41:6 Common Market Law Review 1519 at 1539 phrases the trade-off as one between ex post allocative efficiency and ex ante dynamic efficiency. Static efficiency comprises both allocative and productive efficiency. Whereas productive efficiency is concerned with the production of goods at minimum cost, allocative efficiency involves the ability to allocate scarce resources in such a way as to generate highest utility for society. Dynamic efficiency refers to the extent to which new products or services are introduced. For a more economic description of these concepts in relation to market power, see Massimo Motta, Competition Policy. Theory and Practice (Cambridge, Massachussets: Cambridge University Press, 2004) at 40-64. 
this type of competition, competitive pressure primarily comes from subsequent rather than concurrent competitors. The expectation of getting substantial market power encourages new entrants to introduce disruptive innovations that may enable them to overtake the position of the incumbent. However, if competition for the market is strong, market participants may have less incentive to compete within the market which could negatively affect product variety and prices ${ }^{38}$ Competition in the market tends to come from the leading firms in the market, whereas new entrants typically compete for the market. ${ }^{39}$ When determining whether or not to intervene in a market, competition authorities also have to make a choice between encouraging competition in or for the market. Such a trade-off is present in essential facilities cases too, although it remains implicit in most instances.

The Microsoft case can be used to illustrate the balancing exercise in essential facilities cases. By finding that Microsoft's refusal to deal amounted to abuse of dominance, the General Court forced Microsoft to provide its competitors in the market for work group server operating systems with the necessary interoperability information. In so doing, the General Court chose to favour competition in the market over competition for the market. Indeed, by entitling competitors in the market for work group server operating systems access to Microsoft's technology, the General Court stimulated competition on the basis of price and output but also created room for follow-on innovation to flourish. If the General Court alternatively had declined to intervene in the market and had decided that Microsoft's behaviour was not abusive, competitors would not have been able to compete on static parameters or to introduce sustaining innovations in the form of complementary or substitutable products for Windows. Rather, the incentives to invest in innovation of Microsoft's competitors would be directed at developing a new technology disrupting the market for client PC operating systems. By keeping the market for work group server operating systems open, the General Court thus decided to give priority to

38 Ashwin van Rooijen, “The Software Interface Between Copyright and Competition Law. A Legal Analysis of Interoperability in Computer Programs" in P.B. Hugenholtz, ed, Information Law Series (Alphen aan den Rijn, Netherlands: Kluwer Law International, 2010) at 34-36.

39 Christensen refers to "asymmetric motivation" as a cause for the fact that leading companies usually only introduce sustaining innovations that better serve their current customers and thus only compete within the market, while disruptive innovation comes from new entrants that compete for the market. See C.M. Christensen \& M.E. Raynor, supra note 31 at 35. 
static competition and sustaining innovation in existing markets over disruptive innovation in new products or services having the potential to make current market structures obsolete and in particular Microsoft's dominance in client PC operating systems. Nevertheless, the European Commission nor the General Court explained why static competition and sustaining innovation should prevail over disruptive innovation in this case. ${ }^{40}$

\section{B. Competition in versus competition for the market}

Current competition law is equipped to deal with short term concerns. Incentives for competition for the market are hard to accommodate in competition analysis, because they involve long term considerations about market developments that are by their nature difficult to predict. Since both competition in and for the market contribute, albeit in a different manner, to societal welfare, the decision which type of competition should receive preference amounts to a policy issue. It is therefore a valid policy option for competition authorities and courts to favour competition in the market which is easier to anticipate and leads to observable results on the short run in the form of increased competition in downstream markets, lower prices and more product variety. ${ }^{41}$ Nevertheless, this does not mean that incentives for competition for the market should be disregarded. In order to make the trade-off transparent, it is submitted that incentives for competition for the market should be explicitly considered in essential facilities cases even if preference is given to competition in the market.

Competition for the market, in principle, cannot be revitalised by way of an intervention of a competition authority. This is because this type of competition and the disruptive innovation that it generates is by nature hard to foresee. The business literature discussed above indicates that new products or services that render existing market structures obsolete are typically developed by new entrants instead of by current market players which are more inclined to stay close to their existing customers. Indeed, many of the disruptive inventions present in the technology industry today come from small start-ups which were initially run by only a few people. Examples include companies such as Skype and WhatsApp (now acquired

\footnotetext{
$40 \quad$ See Pierre Larouche, “The European Microsoft Case at the Crossroads of Competition Policy and Innovation" (2008) 75:3 Antitrust Law Journal 601 at 610-611, 613.

$41 \quad$ See D. Geradin, supra note 37 at 1540.
} 
by respectively Microsoft and Facebook) which started to attack the business model of telecommunications operators by enabling users to make free calls and send free messages over the internet without having to rely on the telephone network of their telecom provider.

In order to preserve incentives for competition for the market and disruptive innovation, the best approach for competition authorities is to refrain from intervening in order to ensure that the prospect of dominance for new entrants is maintained. In Trinko, the US Supreme Court stated that the possession of monopoly and the charging of monopoly prices is an important element of the free-market system: "The opportunity to charge monopoly prices-at least for a short period-is what attracts 'business acumen' in the first place; it induces risk taking that produces innovation and economic growth" ${ }^{42}$ A competition law intervention may thus lower incentives for competition for the market.

The only type of innovation that a competition law intervention can directly stimulate is sustaining innovation which results from competition in the market. The imposition of a duty to deal in essential facilities cases enables competitors to introduce complementary products and follow-on innovation, whereas in the absence of a competition law intervention no sustaining innovation can occur and competitors will instead invest in disruptive innovation. Nevertheless, the creation of competition in the market by way of competition enforcement may indirectly create room for the disruptive inventions of competitors to gradually take over the leading position of the incumbent by making its dominance in the existing market less significant..$^{43}$ The effects of the enforcement actions of the United States Department of Justice and the European Commission against the integration of Microsoft's web browser Internet Explorer in its client PC operating system may serve as an example.

Both institutions entered into a settlement with Microsoft in order to bring the tying of Internet Explorer to Windows to an end. ${ }^{44}$ While the

$42 \quad$ Trinko, supra note 7 at 407.

43 Gintare Surblyte, "The Refusal to Disclose Trade Secrets as an Abuse of Market Dominance - Microsoft and Beyond" in J. Drexl, ed, Munich Series on European and International Competition Law, vol. 28 (Bern, Switzerland: Stämpfli Publishers Ltd., 2011) at 131.

44 See United States $v$ Microsoft Corp., 231 F Supp (2d) 144 (D.D.C. 2002); Microsoft (tying), COMP/C-3/39.530, 16 December 2009. 
actions had as their objective to restore competition in the market for web browsers, the commitments arguably also had as their effect that scope was created for competition for the market in the form of a market shift to Google and other internet players which has made the dominance of Microsoft in the market for client PC operating systems less important. By opening up the market for web browsers, the US DOJ and the European Commission can thus considered as having imposed competitive pressure on Microsoft which possibly distracted the company and enabled the start of a new race of competition for the market.

\section{Application to the market characteristics of the digital economy}

Competition law interventions can thus only have an indirect impact on competition for the market, as the effects of the US and EU enforcement actions against Microsoft's tying of Internet Explorer to Windows illustrate. It is impossible for a competition authority or court to directly re-establish the process of competition for the market. This is because this type of competition and the disruptive innovation that it generates is by nature difficult or even impossible to predict. Incentives to invest in disruptive innovation can be negatively affected due to a too interventionist policy of competition enforcement. The prospect of a dominant position may be necessary for incentivising investment in new types of disruptive innovation. The imposition of far-reaching competition remedies could curb those incentives.

Nevertheless, in order to keep the price level and the product variety at a competitive level, competition authorities should intervene when necessary to ensure a certain degree of competition in the market. This will also put the incumbent under pressure to fight for maintaining its leading position in line with its incentive to pre-empt the entry of potential competitors. ${ }^{45}$ In the words of former Director-General for Competition Italianer: "history tells us that competition for the market, as exemplified by disruptive innovations which introduce totally new business models in high tech markets, may happen slower than predicted. Take mainframes or PC operating systems as examples: they have had stable market presence for

See section II.B. above. 
decades. There is therefore a need to foster competition not only for the market but also in such markets". ${ }^{46}$

As result, the presence of competition in and for the market has to be in balance in order to have a healthy competitive environment. Since the two types of competition cannot be equally present in a market at the same point in time, the balance should rather be seen as one that is established over time. Whereas in sectors predominantly characterised by competition for the market a temporary form of market power is inevitable, the market can still be considered competitive as long as new entrants are able to attack the dominant position of the incumbent. However, the winner of a race for the market should be prevented from extending its gained dominance and from delaying the start of a new round of competition for the market. Competitive pressure can be considered vital in this perspective. ${ }^{47}$ When market dynamics have failed to exert sufficient competitive pressure, competition authorities should intervene in order to restore the level of competition in the market.

The question is how such findings can be applied to the market characteristics of the digital economy. Due to network effects, switching costs and lock-in, digital markets typically have high levels of concentration. As a result, competition for the market prevails. While the presence of large market shares may be precisely what stimulates new entrants to attack the position of incumbents, concern is in place where the market power of established players stabilises and entrenches over time. This may not only delay successful challenges by new "champions" in existing markets but also impede entry in neighbouring markets that tech companies can keep to themselves by leveraging their market power to related activities. Companies like Apple and Google have been extending the reach of their businesses beyond their original remit to develop smart watches, smart glasses, television platforms, self-driving vehicles and even participate in energy management. While such conglomerate strategies are not problematic in themselves and can create welfare-enhancing efficiencies, these developments do illustrate that the way in which competition takes place is changing in the digi-

$46 \quad$ Alexander Italianer, "Prepared remarks on: Level-playing field and innovation in technology markets" (Conference on Antitrust in Technology, Palo Alto, United States, 28 January 2013) at 4.

47 See also Roberto Pardolesi \& Andrea Renda, “The European Commission's Case Against Microsoft: Kill Bill?” (2004) 27:4 World Competition 513 at 528-535. 
tal economy. The ability of tech firms to enter connected markets and engage in "killer acquisitions", namely the acquisition of innovative startups to pre-empt them from becoming future competitors, weakens the self-correcting nature of the market and may delay or even prevent a new wave of competition for the market from occurring. In these circumstances, competition authorities need to be more wary of the risk of "market tipping" that will lower innovation incentives for dominant undertakings as well as competitors.

An issue that can play a crucial role in this regard is whether external market failures materialise. In the presence of external market failures, the fact that the incumbent remains dominant may not result from its competitive success but merely be a consequence of the market situation grown around the incumbent's dominance. The scope for competition enforcement is wider in those cases because a competition law intervention may re-establish the level of competition in the market which market forces itself are unable to achieve. In such situations, it may be reasonable for competition authorities and courts to continue to guarantee competition in the market and protect consumers against abuse of dominance as long as a new wave of competition for the market does not arise.

By lowering the standards for holding a refusal to deal abusive under Article 102 TFEU in Microsoft, the European Commission and the General Court may have deliberately tailored the application of the essential facilities doctrine to the particular market situation in the case. In that light, one could argue that the higher standards established in Magill and IMS Health are still valid for cases in which no external market failures are present. ${ }^{48}$ In such situations, the self-correcting mechanism of the market to adequately address possible competition problems is stronger. As a result, stricter conditions may be applied to prevent that incentives for competition for the market are unnecessarily reduced by taking away the prospect of dominance for new entrants. Although the decision to intervene in a market amounts to a policy choice, the specific characteristics and stage of development of the market may thus inform competition authorities about the appropriate approach in a particular situation. When the market is locked-in due to the presence of network effects or switching costs, and

$48 \quad$ Inge Graef, “Tailoring the Essential Facilities Doctrine to the IT Sector: Compulsory Licensing of Intellectual Property Rights after Microsoft" (2011) 7:1 Cambridge Student Law Review at 18. 
the incumbent has had a stable dominant position for some time, it seems justified for a competition authority to intervene on the basis of looser conditions in order to open up the process of competition in the market through the imposition of a duty to deal. Considering the market characteristics of the digital economy, such situations may become more prevalent.

\section{Analysing the Google Shopping and Google Android cases through the lens of the essential facilities doctrine}

In the context of the digital economy, the essential facilities doctrine is particularly discussed as a tool to open up rankings of search engines and datasets as an input for the development of services. ${ }^{49}$ At the same time, no concrete enforcement actions have been taken at the EU level based on the essential facilities doctrine in the digital economy. The section looks at the decisions of the European Commission in Google Shopping and Google Android and argues that essential facilities-alike remedies have been imposed under lower standards of tying and non-discrimination. This raises the question of whether the Commission is bypassing the stricter essential facilities requirements by expanding the scope of other abuses. Such stretches are not desirable from the perspective of the internal consistency of competition law. This is especially the case if the competition interventions at issue lead to remedies that would normally only be capable of being adopted under the essential facilities doctrine.

\section{A. Google Shopping}

In June 2017, the European Commission imposed a 2.42 billion fine on Google for abusing its dominance in the internet search market by giving illegal advantage to its own comparison shopping service Google Shopping. As explained by the Commission in its decision, the more favourable positioning of Google Shopping is abusive, because it diverts traffic from competing comparison shopping services to Google and is capable of having, or likely to have, anticompetitive effects in the national markets for comparison shopping services and general search services. ${ }^{50}$ In parti-

49 See Marina Lao, "Search, Essential Facilities, and the Antitrust Duty to Deal" (2013) 11:5 Northwestern Journal of Technology and Intellectual Property 272; Zachary Abrahamson, "Essential Data" (2014) 124:3 The Yale Law Journal 867.

50 Google Search (Shopping), AT.39740, 27 June 2017 at para 341 [Google Shopping]. 
cular, the Commission argued that Google's conduct was based on a strategy to push its comparison shopping service that was not successful at its launch. Google entered the comparison shopping market with "Froogle" in 2004. According to the Commission's findings, Froogle was not gaining traffic because it did not appear visibly in Google's general search results pages. Only after Google engaged in the alleged abusive conduct, the traffic to Google's comparison shopping service began to increase whereas traffic to other comparison shopping services began to decrease on a lasting basis. ${ }^{51}$ While competing comparison shopping services could only appear as generic search results and were prone to being demoted by certain algorithms, Google's own comparison shopping service was prominently positioned, displayed in rich format and never demoted by those algorithms. ${ }^{52}$

Google uses generic search algorithms to rank web pages and applies adjustment mechanisms "to improve the user experience". ${ }^{53}$ The Panda algorithm demoted sites with low original content, a feature inherent to comparison shopping services. ${ }^{54}$ As a result, comparison shopping services could only be displayed as generic search results and not be displayed in rich format, with pictures and additional information on the products and prices. ${ }^{55}$ However, Google Shopping was not subject to the Panda algorithm and was displayed in rich format in the general search results. ${ }^{56}$ According to the Commission, Google was aware that Froogle's market performance was poor and that Froogle would not rank highly in Google's general search results pages if it were subject to the same ranking mechanisms. A Google executive wrote in an internal document: "Froogle simply doesn't work" ${ }^{57}$

As regards the theory of harm, the Commission seems to base itself on the notion of "leveraging". The Commission argued that Article 102 TFEU also prohibits "conduct of an undertaking with a dominant position in a given market that tends to extend that position to a neighbouring but separate market by distorting competition". ${ }^{58}$ According to the Commission,

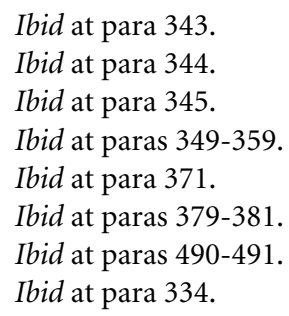


this is not a novel finding as such a form of conduct "constitutes a wellestablished, independent, form of abuse falling outside the scope of competition on the merits" ${ }^{99}$ In response to Google's argument that the Bronner criteria should have been applied, the Commission argued that they were irrelevant in the present case. First, in the view of the Commission, the conduct did not concern a passive refusal by Google to give competing comparison shopping services access to a proportion of its general search results. Instead, the Commission qualified the conduct as "active behaviour relating to the more favourable positioning and display by Google" of its own comparison shopping service. ${ }^{60}$ Second, the Commission stated that the Bronner criteria do not apply in a situation, such as that in the present case, where ending the infringement does not involve imposing a duty on the dominant undertaking to "transfer an asset or enter into agreements with persons with whom it has not chosen to contract". ${ }^{11}$ However, such distinctions from "regular" refusal to deal scenarios rather reflect the nature of the input at stake. A search engine crawls and list websites without entering into an agreement with their owners to do so and does not need to transfer "an asset" in order to include websites in its search results.

As a remedy to stop the infringement, the Commission required Google to comply with "the simple principle of equal treatment", as it was phrased in the press release. ${ }^{62}$ In particular, Google had to subject its own comparison shopping service "to the same underlying processes and methods for the positioning and display in Google's general search results pages as those used for competing comparison shopping services", including "all elements that have an impact on the visibility, triggering, ranking or graphical format of a search result". ${ }^{63}$ Interestingly, this outcome is similar to what would have happened if a remedy under the essential facilities doctrine had been adopted. In fact, one can also construe the case as one about a refusal to give access to the prominent spots in the search results, so that the Commission's argument about distinguishing active from passive behaviour

Ibid at para 649.

Ibid at para 650.

Ibid at para 651.

European Commission, Press release, "Antitrust: Commission fines Google 2.42 billion for abusing dominance as search engine by giving illegal advantage to own comparison shopping service" (27 June 2017), online: <http://europa.eu/rapid/ press-release_IP-17-1784_en.htm>.

63 Google Shopping, supra note 50 at para 700. 
does not hold up. By framing the case as one about self-favouring by a dominant undertaking, the Commission chose to disregard the stricter conditions of the essential facilities doctrine. As argued by Google, by failing to apply the Bronner criteria, the Commission imposed a duty on Google to allow "competing comparison shopping services to have access to a significant proportion of its general search results pages" without showing that access to those pages is indispensable for them to compete. ${ }^{64}$

A question is whether an analogy can be made with constructive refusals to deal, and in particular margin squeezes. ${ }^{65}$ Constructive refusals to deal can take the form of delaying or degrading the supply of the product or imposing unreasonable conditions for supplying. ${ }^{66}$ To a certain extent, Google's behaviour to demote rival comparison shopping services in its general search results can be argued to constitute such a constructive refusal to deal. The relevant issue then is whether such discriminatory conditions of supply can be considered abusive in the absence of a duty to supply under the essential facilities doctrine. In the context of a margin squeeze, the Court of Justice in its TeliaSonera judgment found that the Bronner criteria do not "necessarily also apply when assessing the abusive nature of conduct which consists in supplying services or selling goods on conditions which are disadvantageous or on which there might be no purchaser" ${ }^{37} \mathrm{~A}$ margin squeeze concerns a situation where a vertically integrated dominant firm sets its upstream and downstream prices to such a level to create a margin between them at which downstream competitors cannot make a profit. The Court argued that a margin squeeze "may, in itself, constitute an independent form of abuse distinct from that of refusal to supply" that is not subject to the exceptional circumstances test. ${ }^{68}$ Otherwise, in the Court's view: "before any conduct of a dominant undertaking in relation to its terms of trade could be regarded as abusive the conditions to be met to establish that there was a refusal to supply would in every case have to

$64 \quad$ Ibid at para 645.

65 For a discussion of how the margin squeeze concept can be applied to online platforms, see Friso Bostoen, "Online platforms and vertical integration: the return of margin squeeze?” (2018) 6:3 Journal of Antitrust Enforcement 355. See EC, Communication from the Commission - Guidance on the Commission's enforcement priorities in applying Article 82 of the EC Treaty to abusive exclusionary conduct by dominant undertakings, [2009] OJ, C 45/7 at para 79.

67 Konkurrensverket $v$ TeliaSonera Sverige AB, C-52/09, ECLI:EU:C:2011:83 at para 55.

$68 \quad$ Ibid at para 56. 
be satisfied, and that would unduly reduce the effectiveness of Article 102 TFEU". 69

It remains to be seen whether the finding of the Court in TeliaSonera that a duty to deal does not have to be established in the context of margin squeezes also applies to other types of conduct. The reference to "terms of trade" in the last quote seems to provide the Court with the opportunity to expand its line of reasoning to other forms of discriminatory conduct as well. In its December 2018 Slovak Telekom judgment, the General Court did point to the fact that the Court of Justice in TeliaSonera did not particularly refer to margin squeeze as a form of abuse "but rather to the supply of 'services or selling goods on conditions which are disadvantageous or on which there might be no purchaser' and to 'terms of trade' fixed by the dominant undertaking". According to the General Court in Slovak Telekom: "Such wording suggests that the exclusionary practices to which reference was therefore made concerned not solely a margin squeeze, but also other business practices capable of producing unlawful exclusionary effects for current or potential competitors, like those classified by the Commission as an implicit refusal to supply access to the applicant's local loop" ${ }^{70}$ A question is whether this would also include the self-favouring at stake in Google Shopping. The Commission has not relied upon this theory of harm in its decision so that it will be interesting to see whether it comes up in the appeal before the General Court.

However, a broad non-discrimination principle would go against the objective of competition law. It is the ability of firms to effectively compete against rivals that is protected under competition law, rather than to ensure that all players in the market are able to offer the same products under the same conditions. ${ }^{71}$ As a result, if the General Court and possibly, at a later instance, the Court of Justice support the Commission in bypassing the stricter requirements of the essential facilities doctrine, there is a need to adopt limiting principles to prevent that any form of self-favouring is considered problematic in itself.

Ibid at para 58.

Slovak Telekom, T-851/14, ECLI:EU:T:2018:929 at para 126.

P. Ibanez Colomo, "Exclusionary discrimination under Article 102 TFEU” (2014) 51:1

Common Market Law Review 153. 


\section{B. Google Android}

A year after the Google Shopping decision, in July 2018, the Commission imposed another fine of 4.34 billion euro on Google for behaviour relating to its Android mobile operating system. In particular, the Commission alleged that Google was using Android as a vehicle to cement its dominance in online search. Three types of contractual restrictions were regarded as abusive, namely: (1) requiring Android device manufacturers to pre-install the Google Search app and the browser app Chrome as a condition for licensing the Google Play Store, (2) making payments to certain manufacturers and mobile network operators on the condition of exclusively pre-installing the Google Search app on their devices, and (3) preventing manufacturers wishing to pre-install Google apps from selling even a single smart mobile device running on alternative versions of Android that were not approved by Google (so-called "Android forks"). ${ }^{72}$ The first type of behaviour is relevant here.

The requirement imposed by Google on Android device manufacturers to pre-install Google Search and Chrome as a condition for being able to license the Google Play Store is qualified by the Commission as a form of tying. According to the Commission's investigation, the Google Play Store was a must-have product that users expect to find pre-installed on mobile devices and was used by Google as the "tying product" to strengthen its position in the markets for the "tied products" Google Search and Chrome. However, the outcome that the Commission aims to achieve more closely resembles an essential facilities claim. ${ }^{73}$ In previous tying cases, the alleged harm consisted in the fact that once consumers decide to purchase the tying product (for instance the Windows operating system in the Microsoft tying case of 2009), they are provided with the tied product (namely the Internet Explorer browser) as well. However, the Google Android case relates to the conditions under which manufacturers can have access to Google's vertically integrated platform. The situation the Commission

European Commission, supra note 62.

See also Pinar Akman, "A Preliminary Assessment of the European Commission's Google Android Decision" (December 2018), online: Competition Policy International $<$ https:/www.competitionpolicyinternational.com/wp-content/uploads/2018/12/ CPI-Akman.pdf $>$; Konstantinos Stylianou, "Help Without Borders: How the Google Android Case Threatens to Derail the Limited Scope of the Obligation to Assist Competitors" (2016) SSRN Working Paper, online: <https://papers.ssrn.com/sol3/papers. cfm?abstract_id=2766062>. 
aims to address is one where manufacturers who do not want to pre-install Google Search and Chrome on their mobile devices will not get a license for the Google Play Store. As a result, the abuse can also be argued to relate to the conditions under which access is granted to the Google Play Store, rather than the tying as such. In other words, the concerns does not so much relate to the fact that access to the Google Play Store implies getting access to Google Search and Chrome as well, but rather refers to the situation that manufacturers that want to pre-install third-party applications are asking access to Google Play Store. This would turn Google's refusal to license the Play Store as a separate product, independent from whether manufacturers also pre-install Google Search and Chrome on their devices, a potential refusal to deal offense, instead of a tying offense. As a result, the stricter conditions of the essential facilities doctrine would then apply.

Although the Commission decision in Google Android was not yet available at the time of writing, it is worth pointing at a March 2019 statement by Commissioner Vestager arguing that: "The Decision means that Google can no longer oblige device manufacturers to take Google's search and browser products if they take the Google Play Store" ${ }^{74}$ This indeed suggests that the decision aims to address the conditions under which Google should license the Play Store to manufacturers, rather than to simply unbreak a tie. This is acknowledged by the Commission in an earlier press release stating that "Google's licensing conditions make it impossible for manufacturers to pre-install some apps but not others" ${ }^{75}$

Interestingly, Google now intends to provide a choice screen for Android users in Europe for existing as well as new Android phones where Google is pre-installed, so that consumers can choose the search and browser provider on their Android phone. ${ }^{76} \mathrm{~A}$ choice screen was also implemented by Microsoft to address the tying of the Internet Explorer web browser to the Windows operating system in $2009 .{ }^{77}$ However, a choice screen does not seem capable to fully take away the concerns the Commission identified in Google Android. Considering that the key issue is the inability of manufac-

74 Statement by Commissioner Vestager on Commission decision to fine Google 1.49 billion for abusive practices in online advertising, 20 March 2019, online: <http:// europa.eu/rapid/press-release_STATEMENT-19-1774_en.htm> [Statement by Commissioner Vestager].

75 European Commission, supra note 62.

76 Statement by Commissioner Vestager, supra note 74.

77 Microsoft (tying), supra note 44. 
turers to get a license for the Play Store without having to pre-install Google Search and Chrome on their devices, making it easier for consumers to download third-party applications through a choice screen does not completely address the anticompetitive effects of Google's conduct. In a press release, the Commission referred to the two-fold impact of Google's practices, namely (1) a reduction of the incentives of manufacturers to pre-install competing search and browser apps, and (2) a reduction of the incentives of users to download such apps. ${ }^{78}$ A choice screen would only address the latter effect. Adequate remedies addressing the first effect inevitably relate to the conditions under which Google grants access to its Play Store, so that the result will be more akin to an essential facilities, rather than a tying, case.

\section{Developments outside EU competition law}

Beyond the field of EU competition law, there are other relevant developments relating to access to rankings and data at the national as well as EU level. These developments raise questions about the interaction with competition law.

At the national level, the French Loi pour une République numérique introduced a requirement of "platform loyalty" in French consumer law requiring online platforms to provide consumers with information regarding the methods used to rank content. ${ }^{79}$ The French telecom regulator ARCEP is stimulating discussions about device neutrality, ${ }^{80}$ while the French Conseil National du Numérique has suggested to expand the EU net neutrality rules to rankings to establish a form of "platform neutrality". ${ }^{11}$ Such strong national responses risk fragmenting the EU internal market and lead to situations where firms are subject to different requirements

78 European Commission, supra note 62.

79 Art. L. 111-7 II of the French Code de la consommation which was changed accordingly as provided by article 49 of the Loi $n^{\circ}$ 2016-1321pour une République numérique adopted on 7 October 2016.

80 ARCEP, Smartphones, tablets, voice assistants... Devices: weak link in open internet access. Report on their limitations and proposals for corrective measures (February 2018), online: $<$ https://www.arcep.fr/uploads/tx_gspublication/rapport-terminaux-fev2018-ENG. pdf $>$.

81 Conseil National du Numérique, "Platform Neutrality. Building an open and sustainable digital environment", May 2014, online: <https://cnnumerique.fr/files/uploads/2014/ 06/PlatformNeutrality_VA.pdf $>$. 
and consumers benefit from different levels of protection, depending on the proactiveness of national regulators. Political agreement has been reached in February 2019 on an EU Regulation on promoting fairness and transparency for business users of online intermediation services. ${ }^{82}$ Article 5 of the Regulation contains a provision requiring platforms to be transparent in their terms and conditions about the main parameters determining ranking as well as the relative importance of those main parameters as opposed to others. However, beyond transparency no strict conditions are imposed, so that the Regulation leaves room to Member States to regulate this issue further at national level.

At the EU level, the European Commission is stimulating the sharing and reuse of data within its European Data Economy initiative. ${ }^{83}$ In April 2018 , the Commission published a document providing guidance on sharing private sector data ${ }^{84}$ In some industries like agriculture and automotive, sector-specific measures are being developed to increase data access. ${ }^{85}$ The Payment Services Directive 2 now provides payers with the right to make use of payment initiation and account information services, facilitating third party service providers either to access a bank's infrastructure to initiate a payment or to access a payer's payment account information in order to consolidate account information from one or more accounts into one application. ${ }^{86}$ What these initiatives have in common is that are appli-

82 European Commission, Press release, "Digital Single Market: EU negotiators agree to set up new European rules to improve fairness of online platforms' trading practices" (14 February 2019), online: <http://europa.eu/rapid/press-release_IP-19-1168_en. htm>.

83 Communication from the Commission to the European Parliament, the Council, the European Economic and Social Committee and the Committee of the Regions, "Building a European Data Economy", 10 January 2017, COM(2017) 9 final; Communication from the Commission to the European Parliament, the Council, the Economic and Social Committee and the Committee of the Regions, "Towards a common European data space", 25 April 2018, COM/2018/232 final.

84 Commission Staff Working Document, "Guidance on sharing private sector data in the European data economy", 25 April 2018, SWD(2018) 125 final.

85 See Copa-Cogeca, EU Code of conduct on agricultural data sharing by contractual agreement, 2018, online: <https://copa-cogeca.eu/img/user/files/EU\%20CODE/EU_Code _2018_web_version.pdf>; Communication from the Commission to the European Parliament, the Council, the European Economic and Social Committee, the Committee of the Regions, "On the road to automated mobility: An EU strategy for mobility of the future", COM/2018/283 final.

86 Articles 66 and 67 of the Directive (EU) 2015/2366 of the European Parliament and of the Council of 25 November 2015 on payment services in the internal market, amending 
cable to all players in the market through providing access to data as an input for the development of new services in a horizontal way, side-stepping the case-by-case assessment of the essential facilities doctrine under competition law that would only support claims against dominant firms. Although it is a policy choice to adopt horizontal legislation to facilitate broader access to data, the trade-offs (sustaining versus disruptive innovation; competition in versus competition for the market) that competition law makes could also inform policies in other areas. While economic modelling has already pointed to the desirability of data sharing regimes in certain circumstances ${ }^{87}$ empirical studies would be desirable to point out which markets benefit from such a horizontal regulatory intervention.

As a result, the case-by-case assessment of competition law has advantages because it can tailor interventions to tackle the factual circumstances. In addition, competition interventions can be based on an assessment of their short- and long-term effect on the market. While a revival of the essential facilities doctrine cannot address all situations of a lack of access to rankings or data, it would lower the need for the adoption of new legislation or policy measures in cases where a dominant firm acts as a gatekeeper to markets. Failure of competition law to act may also provide room for EU or national legislators to intervene in a way that does more harm than good, for instance due to lobbying by corporate giants trying to adjust new regimes in a way that furthers their interests. Competition enforcement is generally less perceptive to such forces.

In this regard, it is interesting to note that the Commission has reportedly started a competition investigation against Amazon for its use of data from rival retailers. ${ }^{88}$ Depending on how the investigation evolves, it may set a precedent so that the enforcement action has a spill-over effect resulting into broader access to data without the need to adopt horizontal

Directives 2002/65/EC, 2009/110/EC and 2013/36/EU and Regulation (EU) No 1093/ 2010, and repealing Directive 2007/64/EC [2015] OJ L 337/35.

87 Cédric Argenton \& Jens Prüfer, "Search Engine Competition with Network Externalities" (2012) 8:1 Journal of Competition Law and Economics 73; Jens Prüfer \& Christoph Schotmüller, "Competing with Big Data”, Tilburg Law School Research Paper No. 06/ 2017 (TILEC Discussion Paper No. 2017-006, CentER Discussion Paper 2017-007, 16 February 2017), online: $<$ https://papers.ssrn.com/sol3/papers.cfm?abstract_id=2918726 $>$.

88 See Aoife White, "Amazon Probed by EU on Data Collection From Rival Retailers" (19 September 2018), online: Bloomberg <https://www.bloomberg.com/news/articles/ 2018-09-19/amazon-probed-by-eu-on-data-collection-from-rival-retailers $>$. 
legislation. It is unclear what the underlying theory of harm is. The case may be based on a similar notion of self-favouring as applied in Google Shopping, so that there would be a need to find limiting principles considering that, as argued in section 4.1 above, a general notion of non-discrimination in EU competition law is not to be welcomed. In this regard, the EU Regulation on promoting fairness and transparency for business users of online intermediation services also contains in Article 9 a requirement for platforms to include in their terms and conditions a description of the access of business users to any personal data or other data which business users or consumers provide for the use of the online intermediation service or which are generated through the provision of the service. However, the Regulation does not prescribe a minimum level of data access or ban any unfair practices relating to data access.

\section{Proposal for reviving the essential facilities doctrine for the EU digital economy ${ }^{89}$}

There are two limits to the essential facilities doctrine under EU competition law that are particularly relevant for its application in digital markets. These relate to, respectively, the requirement of exclusion of effective competition and the new product requirement.

\section{A. Exclusion of effective competition}

The way in which the requirement of exclusion of effective competition has been applied in previous essential facilities cases on EU level indicates that the relevant question is whether the essential facility holder reserves the downstream market to itself by denying a competitor access to the requested input. In the context of the application of the condition of exclusion of effective competition in Magill, the Court of Justice explicitly stated that the Irish broadcasting stations "reserved to themselves the secondary market of weekly television guides by excluding all competition on that market". ${ }^{90}$ Similarly, in IMS Health, the Court of Justice argued that the refusal was "such as to reserve to the owner of the intellectual property right the market for the supply of data on sales of pharmaceutical

89 The section partly reproduces earlier work in I. Graef, supra note 6 at 220-229, 273276.

90 Judgment in Magill, supra note 10 at para 56. 
products in the Member State concerned by eliminating all competition on that market"..$^{1}$ It can be concluded from these statements that the requirement of exclusion of effective competition aims to target the situation in which an essential facility holder is already active on the downstream market and tries to reserve that market to itself by refusing to deal. Under this interpretation, the condition of exclusion of effective competition does not capture the scenario in which a requesting undertaking needs access to the essential facility in order to enter a market on which the holder of the facility is not (yet) active, because the essential facility holder does not reserve the downstream market to itself by refusing to deal in that situation. In this factual scenario, the downstream market to be entered by the requesting undertaking will typically be a new market. ${ }^{92}$ An existing market implies that others have been able to become active on the market without having access to the input held by the dominant undertaking in the upstream market. In that case, the input to which access is sought does not seem to be indispensable for competition on the downstream market and the access request will likely be rejected for not meeting the first requirement of the essential facilities doctrine. ${ }^{93}$

The question is whether the European Commission and the EU courts will hold on to the current interpretation of the requirement of exclusion of effective competition once they have to decide on a case involving a refusal to deal that prevents the requesting undertaking from opening up a new market. One could argue that it is not likely that such a case will occur because a dominant undertaking does not have an incentive to refuse access in such a situation. Since the essential facility holder is not active on the downstream market that the requesting undertaking would like to enter, it does not have to protect its position on that market and will only gain

91 Judgment in IMS Health, supra note 14 at para 52.

92 See also Ekaterina Rousseva, Rethinking Exclusionary Abuses in EU Competition Law (Oxford: Hart Publishing, 2010) at 125.

93 In Tiercé Ladbroke, the General Court was confronted with a scenario in which the essential facility holder was not present on the downstream market. Ladbroke, a company providing betting services on the Belgian market, was refused a transmission license for sound and pictures of French horse races. One of the reasons why the General Court held that the refusal did not amount to abuse under Article 102 TFEU was that the organisers of the French horse races were not competitors of Ladbroke on the relevant market for the provision of betting services in Belgium and could therefore not be seeking to reserve that downstream market for themselves. See Judgment in Tiercé Ladbroke v Commission, T-504/93, ECLI:EU:T:1997:84 at para 133. 
revenue from selling access to the requested input. The owner of the essential facility may nevertheless be incentivised to refuse access to the requested input if it is planning to become active on the new market itself in the near future. To be effective in such a situation, the requirement of exclusion of effective competition should not entail that the access seeker has to compete with the essential facility holder in the downstream market upon having access to the necessary input. The essential facilities doctrine would then apply to behaviour that does not consist in the leveraging of market power from the upstream market in which the essential facility holder possesses a dominant position into the downstream market in which it wants to strengthen its market position by precluding the entry of competitors. One could argue that the other scenario is more damaging to innovation and consumer welfare than leveraging, because it implies that the owner of the essential facility is capable of preventing the development of a new market by refusing to deal. ${ }^{94}$ Such a scenario is even more relevant for the digital economy where companies may seek access to data in order to introduce a complementary product or service (for instance a statistical or analytics service) and enter a market where the dominant firm is not yet active. ${ }^{95}$ To be effective in such a situation, an essential facilities claim should also be possible in case a refusal to deal blocks the opening up of a new market in which the dominant firm itself is not present. Such an interpretation is particularly desirable in a data-driven economy where such situations are likely to become more prevalent.

\section{B. New product}

The new product requirement is only applied in cases concerning refusals to license intellectual property rights. ${ }^{96}$ However, there is no convincing economic reason for treating refusals to license differently than refusal to deal involving non-intellectual property protected assets. As made clear by the Court of Justice, the new product condition aims to determine whether a refusal to license "prevents the development of the secondary market to the detriment of consumers". ${ }^{97}$ Such damage to con-

\footnotetext{
$94 \quad$ E. Rousseva, supra note 92 at 125.

95 See also J. Drexl, "Designing Competitive Markets for Industrial Data: Between Propertisation and Access", JIPITECH 2017 at 282-283.

96 See judgment in Microsoft, supra note 8 at para 334.

97 Judgment in IMS Health, supra note 14 at para 48.
} 
sumer welfare may occur as well due to a refusal to deal involving an asset not protected by an intellectual property right. Whether essential facility holders are trying to prevent new market developments from occurring is an issue which in principle deserves to be considered for refusals to deal in general and not merely for refusals to license. To tailor the essential facilities doctrine to the digital economy, the applicability of the new product condition could instead be made dependent on whether a market is characterised by external market failures.

External market failures such as the presence of network effects and switching costs may make it commercially unviable for competitors to introduce a new product. If, for instance, consumers are locked-in to a particular standard, a requirement that access seekers have to introduce a new product is of no relevance because consumers are not willing to switch to a different system. Instead of making the applicability of the new product dependent on whether the asset to which access is requested is protected by intellectual property law, the new product condition could differentiate based on whether external market failures occur in the market. Indeed, external market failures may enable the incumbent to extend its dominance in time irrespective of whether the asset to which access is requested is protected by an intellectual property right or not. It is submitted that the essential facilities will be better able to adequately address all scenarios in which refusals to deal require competition intervention by adapting the new product requirement in this way. ${ }^{98}$

With regard to situations where external market failures are present, the new product condition should be dropped to ensure that access seekers who intend to introduce sustaining innovations or products similar to that of the dominant undertaking are able to gain access to the necessary

98 This builds on the idea of Drexl who distinguishes between competition by imitation and competition by substitution. The underlying logic of the distinction is that the scope for competition law liability for refusals to deal is wider in situations where external market failures are present. Drexl defines competition by substitution in the following way: "Intellectual property protection reacts to this phenomenon by excluding the freedom to compete by imitation, but does not exclude the possibility to develop a superior intangible good that, qualifying for IP protection or not, would compete with the prior intangible good in the same market (competition by substitution)" [emphasis added] (J. Drexl, "IMS Health and Trinko - antitrust placebo for consumers instead of sound economics in refusal-to-deal cases" (2004) 35:7 International Review of Intellectual Property and Competition Law 788 at 805). 
input so that the process of competition in the market can be (re)launched. The potential competition problems in markets that are characterised by external market failures relate to the fact that an incumbent may try to prolong its dominance by preventing competitors from entering the market and competing on price or through offering better quality products. The imposition of a duty to deal in such markets will open up the process of competition in the market and ensure that price levels and product variety are kept at a competitive level. Therefore, if the market is locked-in due to the presence of network effects or switching costs and the essential facility holder has had a stable dominant position for some time, competition authorities should be able to impose a duty to deal even if the access seeker is not able to indicate a new product that it would like to introduce once given access to the requested input (provided that the other conditions of the essential facilities doctrine are met). IMS Health and Microsoft form examples of such situations where external market failures prevented potential competitors from entering the market by introducing their own products due to the fact that consumers were not interested in switching to a new type of brick structure or client PC operating system.

In situations not characterised by external market failures, however, the new product condition should be applied strictly to encourage investments in innovation. As the process of competition for the market cannot, in principle, be launched by way of a competition law intervention, incentives for this type of competition are best preserved by avoiding government interference in the market and thereby maintaining the prospect of dominance for new entrants. Competition enforcement in markets where external market failures are absent should be subject to stricter conditions, considering that the self-correcting nature of the market is stronger in these circumstances as a result of which a competition law intervention to encourage competition in the market risks unnecessarily lowering incentives for competition for the market. This is also to ensure that a competition intervention only takes place if it results into substantial utility for consumers in the form of a new product. In this regard, the product to be introduced by the access seeker once given access to the requested data should have no or a relatively low degree of substitutability to the product already offered by the essential facility holder. Even though it is not necessary that the new product establishes a new market, it must be of such better quality or have such complementary features that it is not comparable to the existing product of the dominant firm from the perspective of consumers. 
Such an interpretation of the new product requirement would bring the essential facilities doctrine more in line with the underlying economic interests and the trade-off between competition for and in the market. The new product requirement is a perfect tool to do so, as it can differentiate based on the type of competition or innovation that is at risk in a particular market situation. The reliance on the existence of external market failures as a trigger for the application of the new product requirement would make the essential facilities doctrine more fit for the digital economy. The key issue for determining the presence of external market failures would be whether market characteristics enable a dominant firm to artificially extend its dominance in time.

A lowering of the threshold for the application of the essential facilities doctrine has already been suggested specifically for datasets that are created as a by-product of the delivery of a service, ${ }^{99}$ but the point made here is that a revision of the new product requirement can be applied in general to any asset involved. This approach is more desirable, as it is based on market characteristics rather than a classification of assets which may lead to more legal uncertainty.

Although the essential facilities doctrine is regularly discussed as a tool to open up markets of digital gatekeepers, it has not been applied recently anymore in EU competition enforcement. It is unclear why this is the case. One explanation for the reluctance to rely on the essential facilities doctrine could be the confusion about the applicable standards after the Microsoft judgment in which the General Court lowered the threshold for access requests to be granted under Article 102 TFEU.

99 See Heike Schweitzer, Justus Haucap, Wolfgang Kerber \& Robert Welker, Modernising the law on abuse of market power. Report for the German Federal Ministry for Economic Affairs and Energy (October 2018), online: <https://papers.ssrn.com/sol3/papers.cfm? abstract_id=3250742> at 5-6: "There are good reasons to think that, depending on the exact setting, the threshold for finding that a refusal to supply data constitutes an abuse may be somewhat lower than the threshold for finding an abuse in cases of a refusal to grant access to infrastructures or to intellectual property rights. This is true in particular if and to the extent that the refusal to grant access relates to data which is generated virtually incidentally and without special investment." 
Interestingly, the recent Google Shopping and Google Android decisions of the European Commission seemingly also impose essential facility-alike remedies but under other theories of harm and less strict conditions. From the perspective of the internal consistency of EU competition law, such a development is not desirable. This is all the more true as the issue can be directly addressed within the essential facilities doctrine by aligning its application with the underlying economic interests. This would also make the essential facilities doctrine more fit for the EU digital economy.

In this regard, it is proposed to reinterpret the new product requirement by making its applicability dependent on the presence of external market failures, rather than the presence of intellectual property rights. External market failures give a dominant firm the ability to artificially extend its dominance in time, due to which there should be more room for competition interventions to create stronger competition in the market. As a result, there should then be no need for access seekers to point at a new product they will introduce based on the input of the dominant firm. In such market circumstances, consumers will benefit from the introduction of sustaining innovations or products similar to that of the dominant undertaking in order to ensure that the competitive price level and product variety is protected. In addition, another precondition to revive the essential facilities doctrine for the EU digital economy is to make sure dominant firms cannot prevent new markets from opening up by refusing to deal. To prevent this, the requirement of exclusion of effective competition should also be considered met when the dominant firm is not itself active on the market that the access seeker wishes to access. A narrow interpretation in line with current decision-making practice and case law will become increasingly problematic in an economy where more and more markets become inter-related due to the role of data as an input for new services.

A rethinking of the essential facilities doctrine along these lines does not only prevent an unnecessary expansion of other abuses, but also ensures a better alignment with sector-specific initiatives that are being developed in relation to access to data and rankings. 